\title{
Problems of, and support for, beginner educators
}

\author{
G. M. Steyn \\ School of Education \\ University of South Africa \\ steyngm1@unisa.ac.za
}

\begin{abstract}
Beginner educators cannot produce their best work and achieve the objectives of the schools that employed them until they have adjusted to the work they are required to do, the environment in which they are to work and the colleagues and learners with whom they have to work. However, it is well known that the transition from student educator to newly qualified educator can be problematic. The best way of supporting and developing novice educators is a clear understanding of their problems and constructive induction programmes that train and sustain them by addressing these issues. The article therefore focuses on the plight of, and support for, beginner educators. It addresses two questions. First, what are the needs and concerns of beginner educators? Second, what strategies can be offered to support beginner educators that will ease their transition into the classroom and reduce attrition early in their careers?
\end{abstract}

\section{Introduction}

For many years there has been an awareness that the transition from student educators to newly qualified educators can be problematic (Turner 1994, 325; Koetsier and Wubbels 1995, 333; Boydell and Bines 1995, 57; Jones 2002, 509-10; Capel 1998, 393; Dowding 1998, 18; Joeger and Boettcher 2000, 104; Wong 2002, 53; Whitaker 2001, 1). Research has focused on the needs and concerns experienced by beginner educators, and on assistance and assessment programmes for them (Bolam, Clark, Jones, HarperJones, Timbrell, Jones and Thorpe 1995; Boydell and Bines 1995; Heaney 2001; Hertzog 2002; San 1999; Whitaker 2001). An awareness of the problems experienced by novice educators and addressing such needs can add to quality teaching in a rapidly changing dispensation. 
The literature suggests that educator preparation programmes seldom fully prepare educators for the profession (Halford 1998, 33). These programmes offer minimal pedagogical knowledge and skills. Frequently, many novice educators have to develop their teaching skills through trial and error. This haphazard development often takes years, by which time many struggling educators have left the classroom (Freiberg 2002, 56). Consequently, they often experience feelings of disillusionment and failure during their first years of teaching (Halford 1998, 33).

Despite this longstanding awareness, induction of novices has not received the priority it deserves (Boydell and Bines 1995, 60). Many induction programmes have also failed to guide and help beginner educators in their transition into the profession. Studies in various countries show that induction of newly qualified educators is often inadequate and ought to be improved (Bolam et al. 1995, 247; Jones 2002, 509; Gill 1998, 94; Wilkinson 1997, 48; San 1999, 28). As a result of poor induction programmes as much as 50 per cent of educators in urban schools in the US, leave the profession within three years (Black 2001, 46; cf Whitaker 2001, 1). Moreover, Wong $(2002,54)$ reports that Lafourche Parish Public schools in Louisiana had an annual attrition rate of 51 per cent. However, after the implementation of induction programmes, the rate dropped to 15 per cent almost immediately.

Although there is still room for improvement, admirable efforts have been made in recent years to ease the entry into teaching. Induction schemes have been devised which assist educators in taking on responsibilities with the necessary support and supervision. Mentors have also been assigned to beginner educators to guide them in taking the first steps of their professional life (Bolam et al. 1995, 247; Freiberg 2002, 56; Harrison 2001, 278; Heaney 2001, 246; Mohr and Townsend 2001, 10; Whitaker 2000, 31; Whitaker 2001, 8).

The focus of this article will be on the plight of, and support for, beginner educators. Two questions arise from this. First: what are the needs and concerns of beginner educators? and second: what strategies can be offered to support beginner educators that will ease their transition into the classroom and reduce attrition early in their careers? To answer these questions it is important first to focus on what staff induction entails.

\section{What is staff induction?}

The literature indicates diverse definitions of induction. Within the teaching profession, induction is often viewed as an extension of professional preparation for teaching, or as an introduction to a new set of required skills and practices not learnt during training or as an orientation programme based on the assumption that training is incomplete (Lyons 1993, 12; Dowding 1998, 18; San 1999, 19). For some researchers it is the period for improvement and transition, and a process whereby novices are supported to demonstrate competence during the first year of teaching (Dowding 1998, 18). Unfortunately, the latter view includes an appraisal component which induction should 
not have. Induction is a positive, caring and uplifting experience, which should be distinguished from appraisal (Dowding 1998, 18). Furthermore, educator induction is also incorrectly viewed as orientation or information transmission (Dinham 1992, 30). Although all of the above occurs in the induction programme, educator induction is better understood as an ongoing process, which includes both formal and informal elements of socialisation and professional development, extending from preservice training into the teaching profession. For the purpose of this article induction can be defined as the school's effort to enable and assist new staff members to adjust effectively to their new work environment with the minimum disruption and as quickly as possible, so that the school's functioning can proceed as effectively as possible (Castetter 1996, 182).

Staff induction programmes usually include the following aspects:

- Matters relating to the school: This aspect, inter alia, includes the school culture, vision, mission, values, school policy, financial and physical resources and the curricular and administrative services offered by the school (Canter and Canter 1999, 28; Gill 1998, 99; Heyns 2000, 162).

- Staff related matters: Beginner educators require an understanding of the school's organisational structure, work allocation, job requirements for staff and sound interpersonal relationships (Canter and Canter 1999, 28; Heyns 2000, 162; Whitaker 2001, 2).

- Teaching and the school's curriculum: Classroom management, academic area policies, teaching paradigms as well as effective tuition skills and techniques require attention (Canter and Canter 1999, 28; Freiberg 2002, 57; Gill 1998, 98; Heyns 2000, 162; Whitaker 2001, 2; Wong 2002, 52).

- Learner-related matters: Beginner educators often experience difficulties with individual differences in the classroom (Heyns 2000, 162; Whitaker 2001, 2). Classroom discipline, communication with learners and dealing with learners with behavioural problems often create critical challenges to beginners (Canter and Canter 1999, 28; Heyns 2000, 162; Martin and Baldwin 1996, 107; Whitaker 2000, 31).

- Educator-parent relationships: Difficulties in working and communicating with parents are common among novice educators (Heyns 2000, 162).

- Physical and financial resources: Beginner educators should be acquainted with the school buildings and fixed assets such as teaching materials and equipment (Canter and Canter 1999, 28; Heyns 2000, 162). They also require the necessary skills in financial management.

- Administration: The administrative workload, such as attendance registers, assessment forms and classroom stocktaking, often causes frustration and stress among beginner educators (Canter and Canter 1999, 28; Dowding 1998, 18; Heyns 2000, 162). 
The main purpose of staff induction is to integrate newly appointed educators into the new school situation within the shortest time to ensure productivity (Heyns 2000, 161). The following objectives of a staff induction programme may be summarised (Heyns 2000, 161):

- Orientation: Integrating beginner educators into the profession (Dowding 1998, 19; Heyns 2000, 161; Jones, 2002, 509)

- Psychological support: Enhancing the personal and professional welfare of beginner educators (Dowding 1998, 19; Heyns 2000, 161; Jones 2002, 524)

- Teaching skills: Acquiring and developing the necessary knowledge, skills and attitudes for the classroom situation (Dowding 1998, 19; Heyns 2000, 161; San 1999, 28)

- Philosophy of education: Developing reflective practice skills and a commitment to continuous professional development (Dowding 1998, 19; Freiberg 2002, 57; Heyns 2000, 161)

- Fear and insecurity, Reducing feelings of fear, anxiety, insecurity and stress due to the reality shock (Dowding 1998, 19; Heyns 2000, 161; Koetsier and Wubbels 1995, 334; Mohr and Townsend 2001, 9);

- Staff turnover, Reducing the turnover which follows when beginner educators fail to cope and have negative feelings towards the profession (Dowding 1998, 19; Heyns 2000, 161)

- Realistic educator expectations: Assisting educators in creating realistic expectations of the profession (Dowding 1998, 19; Heyns 2000, 161)

- Job satisfaction and a positive attitude towards the school: Creating a supportive school situation which may contribute to educators' job satisfaction and their motivation (Dowding 1998, 19; Heyns 2000, 161)

The needs of beginner educators as well as the needs of schools, form the basis of staff induction programmes (Heyns, 2000, 162; Dowding, 1998, 18). This requires a needs analysis among educators to identify relevant areas for their development.

\section{Understanding beginner educators' needs}

Much of the research dealing with educator induction focuses on the needs and concerns of novice educators. Induction programme planners cannot assume that novice educators are proficient in teaching because they are qualified. The unrealistic optimism of beginner educators should also not mislead programme planners into believe that beginner educators have the situation well under control. In a study done by Mazibuko $(1999,596)$, educators in Swaziland referred to the first weeks as 'boring', 'daunting', 'difficult', 'stressful' and 'frightening'.

During induction novices assume new responsibilities and roles, and are, 
consequently, compelled to face various problems in the workplace (Mohr \& Townsend 2001:9). A review of literature indicates that there are seven factors related to the difficulties many educators face at the beginning of their career (Table 1):

Table 1 Problems faced by beginning educators

\begin{tabular}{|l|l|}
\hline Problem & Characteristic \\
\hline 1. Reality shock & $\begin{array}{l}\text { Distress experienced due to inadequate educator preservice } \\
\text { preparation }\end{array}$ \\
$\begin{array}{l}\text { 2. Weak knowledge and skill } \\
\text { base }\end{array}$ & $\begin{array}{l}\text { Lack of teaching skills and knowledge required of educators in the } \\
\text { classroom } \\
\text { Unclear and confusing expectations of principals, colleagues, } \\
\text { parents and learners } \\
\text { 3. Expectations }\end{array}$ \\
$\begin{array}{l}\text { 4. Isolation } \\
\text { 5. Classroom management } \\
\text { 6ecision-making and routine teaching tasks including working } \\
\text { with learners } \\
\text { 7. Workload }\end{array}$ & $\begin{array}{l}\text { Absence of teaching material, textbooks and own classrooms } \\
\text { Curricular and extracurricular responsibilities }\end{array}$ \\
\hline
\end{tabular}

\subsection{Reality shock}

The reality shock stems in part from a lack of preparation for the demands of teaching (Brock and Grady 1997, 12; Gill 1998, 98; Mohr and Townsend 2001, 9; Whitaker $2001,2)$. When faced with the demands of teaching practice and the gap between their ideals and reality, many beginning educators experience the reality shock (Koetsier and Wubbels 1995, 333).

Novices are confronted with unknown learners, staff, policies and procedures and an unknown curriculum and unfamiliar norms and traditions in the classroom and school (Whitaker 2001, 2). Unlike a shock that passes quickly, becoming accustomed to the daily realities in the classroom and school is a process that can last for two to three years. Many educators also experience 'information overload' (Dinham 1992, 31; Whitaker 2001, 2).

\subsection{Weak knowledge and a low skill base}

Beginner educators frequently complain that the preservice preparation had not prepared them for actual teaching, and that they lack sufficient knowledge and skills (Brock and Grady 1997, 12; Dinham 1992, 31; Mazibuko 1999, 598; San 1999, 28). They require the necessary basic skills for lesson preparation, teaching methods and assessment, pacing lessons, keeping up with the paperwork, classroom administration and time for 
preparing lessons (Capel 1998, 396, 397; Freiberg 2002, 57; Joeger and Boettcher 2000, 104; Wilkinson 1997, 49; Whitaker 2001, 4). They also do not transfer what they know about theory from the preservice training to what is done on a practical basis in the classroom (Whitaker 2001, 2).

\subsection{Expectations}

Beginner educators often experience a gap between the reality of teaching practice and their ideals (Koetsier and Wubbels 1995, 333). They are often confronted with policies, rules, formal procedures, informal rules and customs (Brock and Grady 1997, 13; Canter and Canter 1999, 28; Whitaker 2001, 2; Mazibuko 1999, 599). This may lead to feelings of disillusionment and failure during their first years of teaching (Halford 1998, 33). Unclear and confusing expectations of principals, colleagues, parents and learners add to the confusion and loss of sense of efficacy (Capel 1998, 396-7; Joeger and Boettcher 2000, 105; Wilkinson 1997, 49; Whitaker 2001, 3).

\subsection{Isolation}

Isolation is characterised by geographic and/or professional isolation (Mohr and Townsend 2001, 10; Whitaker 2001, 5). In the school environment educators spend much of their day alone with learners, isolated from contact with other adults (Brock and Grady 1997, 15; Mohr and Townsend 2001, 9; Mazibuko 1999, 597). New educators may also experience social isolation since many schools have close-knit groups with close friendships (Capel 1998, 405). It also happens that newcomers become victims of existing problems among the staff. When the staff are engaged in conflict or negative attitudes towards the principal, the beginner educator is exposed to negativism and disillusionment (Brock and Grady 1997, 17). Furthermore, with their arrival newcomers change the status of the staff structure. Depending on the beginner educator's reputation and talents, professional jealousy and differences may then surface. As a result of this, communication with colleagues, managers and supervisors is a need experienced by educators (Whitaker 2001, 5).

\subsection{Classroom management}

Classroom management and discipline are cited as serious problems for novice educators (Brock and Grady 1997, 17; Capel 1998, 396; Dinham 1992, 31; Freiberg 2002, 58; Hertzog 2002, 26; Joeger and Boettcher 2000, 104; Martin and Baldwin 1996, 107; Mazibuko 1999, 599; Whitaker 2000, 31). In a study done by Herztog $(2002,29)$ in California, she reports that educators revealed the highest number of problems with classroom management, behaviour management and curriculum planning. These findings were supported by Veenman's study (1984) (Whitaker 2001, 3). In studies done by Martin and Baldwin, Gill (1998) reports that many novices feel ill equipped to 
handle classroom realities, routine tasks and making decisions. These problems include working with learners with poor language skills, relationships with learners, working with learners with different abilities and motivating learners (Hertzog 2002, 26; Dowding 1998, 18).

\subsection{Lack of resources}

Many novice educators report the poor working conditions in schools, such as the absence of materials and textbooks (Brock and Grady 1997, 19; Capel 1998, 399; Dowding 1998, 18; Canter and Canter 1999, 28; Joeger and Boettcher 2000, 105; Whitaker 2001,3). An adequate supply of textbooks and teaching materials has a major impact on beginner educators (Joeger and Boettcher 2000, 105). Koeberg's study among beginner educators in schools in Cape Town, South Africa $(1999,96)$ reports that educators who have to 'travel', that is, meet their classes in available vacant rooms, find this adds to their frustration.

\subsection{Workload}

Beginner educators often feel overwhelmed by the complexity and workload of teaching (Brock and Grady 1997, 20; Mohr and Townsend 2001, 10; Capel 1998, 399; Dowding 1998, 18; Whitaker 2001, 3; Mazibuko 1999, 594). Rather than balancing the responsibilities of novices, they are often given more responsibilities, the least desirable courses, extracurricular activities that experienced educators do not want to accept and the most difficult students (Whitaker 2001, 3; Mazibuko 1999, 594).

Considering the above, it is understandable that novices experience a variety of positive and negative emotions (Heyns 2000, 160). They often suffer from fear, anxiety, stress and feelings of inadequacy (Canter 1999, 28; Dowding 1998, 18; Joeger and Boettcher 2000, 105).

To reduce the problems identified by beginner educators, previous research evidence suggests that certain aspects of induction may enable beginner educators to become effective educators (Turner 1994, 326; Harrison 2001, 277; Dowding 1998, 19; Whitaker 2000, 31; Heaney 2001, 247; Whitaker 2001, 7). Owing to the interconnectedness of problems commonly associated with induction, it is possible to identify strategies that can address more than one problem simultaneously (Mohr and Townsend 2001, 10).

\section{Framework for an induction programme}

It is crucial that beginner staff members should receive help in the form of a planned induction programme (Boydell and Bines 1995, 61). Research indicates that induction needs to be at schools and context-specific due to the need for beginner educators to adjust to the school culture (Boydell and Bines 1995, 61; Dinham 1992, 31; Turner 
1994, 339). Moreover, including beginner educators in designing professional development programmes is important. Wilkinson's study (1997) indicated that 87 per cent of educators wanted to choose the assistance they receive, but only 56 per cent said they got what they wanted.

Developmental induction consists of a set of developmental growth opportunities, which attempt to address the needs of beginner educators (Brock and Grady 1997, 42). The developmental induction programme consists of a few steps (cf Brock and Grady 1998, 181).

\section{Step 1: Initial orientation}

Newly appointed beginner educators should report to the school two or more days before its opening so that the school principal can discuss matters such as the school culture, its values, vision, mission and other important matters with beginner educators (Heyns 2000, 163; Wong 2002, 52). Other more personal matters and problems can also be dealt with on this occasion (Heyns 2000, 163).

Orientation is used to provide necessary information to the new educator. This includes a tour of the school, an explanation of the novice's duties, school rules and procedures and the discipline policy, providing the school policy, background information about the community, informing the novice about record keeping, location of resources, school activities and introducing beginner educators to mentors (Bolam et al. 1995, 247; Brock and Grady 1997, 37; Heyns 2000, 163; Wilkinson 1997, 48-51). Wilkinson's study (1997) reveals that a third of the newcomers started teaching without having basic information about school facilities, rules, procedures and expectations for their teaching.

Some of the above information is often contained in a staff handbook, school policy documents, school development plan or school prospectus. Such documents may be provided before the member of staff takes up the post so he or she may read them and absorb the information even before joining the school.

\section{Step 2: The first school day}

On this day beginner educators are exposed to reality (Bolam et al. 1995, 247; Heyns 2000, 163). Mentors could, however, offer beginners important assistance in facing reality (Heaney 2001, 247; Heyns 2000, 163; Mohr and Townsend 2001, 10). On this day novices may be introduced to the other colleagues, and timetables and tasks may be explained (Dowding 1998, 19; Heyns 2000, 163). A feedback session at the end of the day may address problems beginners experienced (Heyns 2000, 163).

\section{Step 3: The first school week}

Induction during this week should be a natural continuation of the first school day 
(Dowding 1998, 19; Heyns 2000, 163). Various school matters can be addressed, such as administrative matters, punctuality, attendance of school activities and assemblies and utilisation of free periods (Dowding 1998, 19; Heyns 2000, 163; Whitaker 2001, 9).

Step 4: Induction during the first school term

This step forms part of long-term professional development (Heyns 2000, 163). During this phase beginners are introduced to as many matters as possible relating directly to their work, but induction during this term is not intended to be comprehensive. Aspects may include an overview of departmental and school policies, time management, classroom management and classroom observation of skilled educators (Freiberg 2002, 56; Gill 1998, 101; Heyns 2000, 163; Hertzog 2002, 26; Martin and Baldwin 1996, 107; Whitaker 2001, 9; Wong 2002, 52).

\section{Step 5: Ongoing assistance and development}

Activities in developmental induction are designed to assist beginner educators to develop and refine those skills they perceive as lacking or needing (Black 2001, 47; Brock and Grady 1998, 181; Koetsier and Wubbels 1995, 339; San 1999, 28). Individual educators have unique needs which require periodic assessments to determine these needs (Brock and Grady 1997, 46).

Unlike many assistance programmes that stop after the first week of school, developmental induction programmes provide ongoing support. The following strategies may be effective (Black 2001, 46; Brock and Grady 1997, 48-50; Whitaker 2001, 7; Wilkinson 1997, 50):

- Periodic meetings with the principal: Information from the principal is critical to beginner educators' understanding of their role and responsibilities as educators. They want the principal to observe them and affirm that their teaching is acceptable. Principals who understand the typical realities of beginner educators can anticipate and address their needs (Halford 1998, 34). The following are strategies that principals can use to assist novice educators:

- Build confidence: Principals can build confidence in their beginner educators and create a climate of trust by alerting them to pitfalls as indicated previously (Whitaker 2001:14). Beginner educators are very sensitive to principals who do not speak, nod or even make eye contact when passing them on the school premises. Commenting on good things they have observed is recommendable.

- Release time: The general notion of providing release time for beginner educators remains controversial (Lyons 1993, 15). Some researchers believe that there are benefits in beginner educators having release time at the beginning of their teaching careers while others have found that some educators (especially infant 
and primary educators) dislike the disruption of their relationship with their classes (Halford 1998, 35). Wong $(2002,53)$ and Whitaker $(2001,13)$ provide a few useful hints principals can use in releasing time for beginner educators.

* Provide time for beginners to observe experienced educators. This offers beginners an opportunity to see a variety of teaching styles. They can learn from watching others solve problems.

* If possible, schedule preparation periods so that the new educator shares planning time with an experienced educator who teaches the same subject.

* Spend individual time with beginner educators.

* Provide a handbook of policies, procedures and forms.

- Institute a support system: It is necessary to provide a support system for newcomers (Jones 2002, 524; Whitaker 2001, 14). Black (2001, 46) suggests regularly scheduled meetings covering specific topics. These meetings can be useful if they do not take up too much of educators' preparation time. Informal sessions may also be held where beginner educators can rehearse new situations before they actually happen. Parent conferences and confrontations concerning discipline are appropriate topics with which to start.

- Assign responsibilities carefully: Beginner educators usually have little experience; many of them have had fewer than 12 weeks of student practice. Under these circumstances it makes sense to coach new educators rather than to put them into difficult situations.

- Consider the workload of beginner educators: Besides their regular workload, beginner educators frequently get burdened with various types of extramural activity that are so time-consuming that other educators do not want to accept them (Whitaker 2001, 13). Considering a realistic workload is therefore necessary (Koetsier and Wubbels 1995, 341).

- Clear expectations: It is necessary for principals to have clear expectations of novices and novice educators should know exactly what is expected of them (Whitaker 2001, 13; Wilkinson 1997, 49). A staff handbook or bulletin can provide important information, but much information has to be conveyed during formal and informal meetings, class visits, and development programmes.

- Support from mentors: Pairing new educators with mentors is a common phenomenon of induction for beginner educators (Black 2001, 46). It has the potential to decrease professional isolation (Mohr and Townsend 2001, 11; Bolam et al. 1995, 247; Heaney 2001, 246).

Evidence from research suggests that mentors with supportive and empathetic personalities who provide structured programmes could be a key to a much improved induction process (Hertzog 2002, 31; Turner 1994, 336). Appropriate mentor selection and training are, however, crucial for effective mentoring (Brock and Grady 1997, 47; Boydell and Bines 1995, 58; Turner 1994, 338; Whitaker 2000, 31). 
Bolam et al.'s study (1995) and Boydell and Bines's (1995) study, both in schools in England, reveal that the role of mentors is ill-understood. Moreover, mentors do not have a clear job description, adequate training or sufficient time to carry out their role well. Literature reveals that effective mentors have a number of tasks and responsibilities to perform. The following can be identified (Bolam et al. 1995, 247; Freiberg 2002, 56; Harrison 2001, 278; Mohr and Townsend 2001, 10; Whitaker 2000, 31; Whitaker 2001, 7, 8):

- to act as a sounding board for the novice's ideas and concerns by holding regular discussions with the beginner educator. Novices often feel left to 'sink or swim' without a mentor (Black 2001, 46).

- to act as a resource for the novice which might include help with finding accommodation, traveling arrangements and information about the area and local facilities.

- to pass on professional knowledge and coach work skills.

- to provide novices with interpersonal support and guidance.

- to advise on staff development programmes and arrange for attendance at any external training programmes. Mentors can help new educators learn and understand educator practice (Bines and Boydell 1995, 59; Halford 1998, 33; Harrison 2001, 278; Stedman and Stroot 1998, 37). Listening to, and discussing, lesson ideas of novices can make novices' own decisions about teaching more meaningful. Novices can also discuss teaching conditions with mentors and decide together what teaching load is best for the mentee's professional development (Mohr and Townsend 2001, 11).

Pairing new educators with mentors is a common phenomenon of induction for beginner educators (Black 2001, 46). Appropriate mentor selection and training are, however, crucial for effective mentoring (Brock and Grady 1997, 47; Boydell and Bines 1995, 58; Turner 1994, 338; Whitaker 2000, 31). Evidence from research suggests that mentors with supportive and empathetic personalities who provide structured programmes could be a key to a much improved induction process (Hertzog 2002, 31; Turner 1994, 336).) A good mentor is 'mature, trustworthy, understanding, a good listener, experienced, has interpersonal skills, and is challenging and encouraging' (School Management Teams 2000, 38). This means that the quality of relationship between the mentor and novice plays an important role (Bolam et al. 1995, 256). Furthermore, since it is necessary for mentors to share their professional expertise on the curriculum and instruction, matching academic areas and grade levels can play a crucial role in effective mentoring (Hertzog 2002, 31, 32; Quin 1994, 7; Whitaker 2001, 12).

Mentors can assist novices in the following ways (Black 2001, 46; Freiberg 2002, 56; Whitaker 2001, 10; Wong 2002, 53): 
- Informational meetings: Information given during the orientation phase needs to be repeated and expanded during the year. Such meetings provide time to convey information and answer questions.

- Seminars and skills training: Seminars can be organised where issues such as instructional techniques, collaborating with parents and management issues can be dealt with (Black 2001, 47).

- Peer observations: Allowing beginner educators release time to observe, visit and acquire material from other educators helps broaden their perspectives. Without access to skills of experienced educators, many beginning educators are unprepared to face the challenges of the classroom (Freiberg 2002, 56).

- Social functions: Functions held during the year provide opportunities for beginner educators to develop collegial relationships and break the isolation of teaching (Shockley et al. 1992, 274).

The best way of supporting, developing and nurturing an attitude of lifelong learning among novice educators is through an induction programme that trains, supports and retains them (Wong 2002, 52; Freiberg 2002, 56). Certain aspects of induction, in particular mentoring, may enable beginner educators to become effective educators (Turner 1994, 326; Harrison 2001, 277; Dowding 1998, 19; Whitaker 2000, 31; Heaney 2001, 247; Whitaker 2001, 7).

\section{Conclusion}

Schools may recruit, select and appoint staff, but beginner educators cannot be expected to produce their best work and achieve the objectives of these schools until they have completely adjusted to the work they must do, the environment in which they are to work, and the colleagues with whom they have to work. It is therefore important to give beginner educators the best possible start in the teaching profession since their input is vital for promoting learning in others (Whitaker 2001, 1).

If quality teaching is required in education, it is necessary to make educator training, support and retention top priorities (Freiberg 2002, 56; Wong 2002, 54). Effective school management of induction is therefore a good investment for the individual, the school and the teaching profession in general. It implies an awareness of problems experienced by novice educators and appropriate strategies to address such needs.

Educator induction can, however, be expensive, labour intensive and costly but it may be justified for the following reasons (Dowding 1998, 20):

- It may motivate educators to remain in the teaching profession.

- Educator stress may be alleviated.

- Negative influence on student learning may be reduced.

- The outcomes of both educators and learners may improve. 
Researchers need to continue to explore the nature, impact and occurrence of needs experienced by educators and the desired assistance necessary to meet educators' needs. They also need to determine the nature and scope of different strategies as educators progress through the steps of various strategies of the induction process.

\section{References}

Boydell, D. and E. Bines. 1995. Managing support for newly qualified teachers in primary schools. Mentoring and Tutoring 3 (1):57-61.

Black, S. 2001. A lifeboat for new teachers. American School Board Journal September 188 (9):46-48.

Bolam, R., J. Clark, K. Jones, G. Harper-Jones, T. Timbrell, R. Jones and R. Thorpe. 1995. The induction of newly qualified teachers in schools: Where next? British Journal of Inservice Education 21 (3):247-260.

Boydell, D. and H. Bines. 1995. Managing support for newly qualified teachers in primary schools. Mentoring and Tutoring Summer 3 (1):57-61.

Brock, B. L. and M. L. Grady. 1997. From first-year to first-rate. Principals guiding beginning teachers. Thousand Oaks, Calif.: Corwin Press.

Brock, B. L. and M. L. Grady. 1998. Beginning teacher induction programs: The role of the principal. The Clearing House January/February 71 (3):179-183.

Canter, L. and M. Canter. 1999. The right start. Managing Schools Today 8 (7):28-30.

Capel, S. 1998. The transition from student teacher to newly qualified teacher: Some findings. Journal of In-service Education 24 (3):393-409.

Castetter, W. B. 1996. The human resource function in education administration. 6th ed. Englewood Cliffs, New Jersey: Prentice Hall.

Dinham, S. 1992. Teacher induction: Implications for administrators. Practising Administrator, 14 (4):30-33.

Dowding, G. 1998. Beyond survival: Supporting beginning teachers through effective induction. The Practising Administrator 20 (2):18-20.

Freiberg, H. J. 2002. Essential skills for new teachers. Educational Leadership, March, 59 (6):5660.

Gill, M. 1998. Beginning teachers as experts in making. English in Australia July, 122:94-103.

Halford, M. 1998. Easing the way for new teachers. Educational Leadership 55 (5):33-35.

Harrison, J. K. 2001. The induction of newly qualified teachers. Journal of Education for Teaching, November 27 (3):277-279.

Heaney, S. 2001. Experience of induction in one local education authority. Mentoring and Tutoring, December 9 (3):242-254.

Hertzog, H. S. 2002. 'When, how, and who do I ask for help?' Novices' perceptions of problems and assistance. Teacher Education Quarterly 29 (3):25-41.

Heyns, M. 2000. Quality education: revival of staff induction in schools. South African Journal of Education 20 (2):160-296.

Joeger, R. and Boettcher, G. 2000. A description of the nature and impact of teaching events and forms of beginner teacher assistance. Journal of Agricultural Education 41 (4):104-115.

Jones, M. 2002. Qualified to become good teachers: A case study of ten newly qualified teachers during their year of induction. Journal of Inservice Education 28 (3):509-526.

Koeberg, J. C. 1999. The induction and professional socialisation of beginner teachers in Cape Town schools. Mini-thesis. University of the Western Cape. 
Koetsier, C. P. and T. Wubbels. 1995. Bridging the gap between initial teacher training and teacher induction. Journal of Education and Teaching 21 (3):333-345.

Lyons, J. 1993. Ignore, induct or develop? Implementing effective beginning teacher development strategies. The Practising Administrator 15 (2):12-16.

Martin, N. K. and Baldwin, B. 1996. Helping beginning teachers foster healthy classroom management: Implications for elementary school counselors. Elementary School Guidance and Counselling December 31 (2):106-113.

Mazibuko, E. Z. 1999. Understanding the experiences of beginning secondary school teachers. International Review of Education November 45 (5-6):589-602.

Mohr, D. J. and J. S. Townsend. 2001. In the beginning: New physical education teachers' quest for success. Teaching Elementary Physical Education July 12 (4):9-11.

Quinn, L. F. 1994. The importance of structure in providing uniform quality in mentoring/induction programs. Mentoring and Tutoring, 2 (1):5-11.

San, M. M. 1999. Japanese beginning teachers' perceptions of their preparation and professional development. Journal of Education and Teaching April 25 (1):17-29.

School Management Teams. 2002. Employment, induction and orientation of school-based educators. Pretoria: Department of Education

Shockley, R. J., R. Tocha and F. G. Tracy. 1992. School administrator's factomatic. Englewood Cliffs, NJ: Prentice-Hall.

Stedman, P. and S. A. Stroot. 1998. Teachers helping teachers. Educational Leadership, $55(5): 37-38$.

Turner, M. 1994. The management of the induction of newly qualified teachers in primary schools. Journal of Education and Teaching 20 (3):325-341.

Whitaker, S. D. 2000. What do first year special education teachers need? Implications for induction programmes. Teaching Exceptional Children September/October 33 (1):28-36.

- 2001. Supporting beginning special education teachers. Focus on Exceptional Children December 34 (4):1-18.

Wilkinson, G. A. 1997. Beginning teachers identify gaps in their induction programs. Journal of Staff Development Spring 18 (2):48-51.

Wong, W. H. 2002. Induction: the best form of professional development. Educational Leadership, March, 59 (6):52-54. 